J. Dairy Sci. 92:5133-5138

doi:10.3168/jds.2009-2210

(c) American Dairy Science Association, 2009.

\title{
The effect of dietary iodine supplementation in dairy goats on milk production traits and milk iodine content
}

\author{
A. Nudda,${ }^{* 1}$ G. Battacone, ${ }^{*}$ M. Decandia, $\dagger$ M. Acciaro, $†$ F. Aghini-Lombardi,‡ M. Frigeri, $\ddagger$ and G. Pulina* $†$ \\ *Dipartimento di Scienze Zootecniche, University of Sassari, 07100 Sassari, Italy \\ †Agricultural Research Agency of Sardinia-AGRIS Sardegna, Loc. Bonassai, 07100 Sassari, Italy \\ †Dipartimento di Endocrinologia e Metabolismo, University of Pisa, 56124 Pisa, Italy
}

\section{ABSTRACT}

Dairy products offer an important source of iodine for humans, particularly infants and children. An adequate iodine content in the diet of lactating animals must guarantee a suitable milk iodine concentration. In this experiment, the effects of iodine supplementation of dairy goat diets on the iodine concentration, milk yield, and milk composition of goat milk were studied. Thirty crossbred dairy goats of the Sarda population were divided into 3 groups supplemented with 0 (control group), 0.45 (group 1), or 0.90 (group 2) $\mathrm{mg}$ of $\mathrm{KI} / \mathrm{d}$ per goat. The dose of KI ( $76.5 \%$ of iodine) was dissolved in water and orally administered with a syringe every day for $10 \mathrm{wk}$. Mean milk iodine concentrations were $60.1 \pm 50.5,78.8 \pm 55.4$, and $130.2 \pm 62.0 \mu \mathrm{g} / \mathrm{L}$ (mean $\pm \mathrm{SD}$ ) in the control group, group 1, and group 2 , respectively. The extent of iodine enrichment in milk was approximately $31 \%$ in group 1 and $117 \%$ in group 2 compared with the control group. Milk yield was not influenced by KI supplementation and averaged 1,229, 1,227 , and $1,179 \mathrm{~g} / \mathrm{d}$ in groups 0,1 , and 2 , respectively. Milk urea nitrogen concentration was significantly lower in the KI-supplemented groups (32 and $33 \mathrm{mg} / \mathrm{dL}$ in groups 1 and 2, respectively) than in the control group $(37 \mathrm{mg} / \mathrm{dL})$. Iodine supplementation of dairy goat diets can increase milk iodine content without adverse effects on milk production traits.

Key words: milk, iodine, dairy goat

\section{INTRODUCTION}

Iodine is an essential nutrient of humans and animals because it is needed for the synthesis of the thyroid hormones thyroxine and triiodothyronine. Adolescents and adults need iodine in amounts of $150 \mu \mathrm{g} / \mathrm{d}$, children younger than $2 \mathrm{yr}$ old need $90 \mu \mathrm{g} / \mathrm{d}$, and pregnant and lactating woman need $250 \mu \mathrm{g} / \mathrm{d}$ (World Health

Received March 13, 2009.

Accepted June 23, 2009.

${ }^{1}$ Corresponding author: anudda@uniss.it
Organization, 2007). The iodine requirement exceeds the availability of iodine from environmental sources (i.e., air, food, and water) in many regions of the world, resulting in the development of iodine deficiency disorders (IDD) in humans (de Benoist et al., 2008). In particular, neurological deficits or impaired mental development in children has been ascribed to IDD (Vitti et al., 2001; Delange, 2002). In areas with IDD, iodine intervention programs, such as supplementation of the diet with iodized salt or modified foods, can provide benefits to consumer health.

Dairy products could offer an additional source of iodine intake for humans, particularly infants and children, at an age when the use of iodized salt should be limited. Beneficial contamination of milk with iodine already occurs when dairy farmers use commercial iodophor sanitizers for teat disinfection (Galton et al., 1986).

Iodine deficiency disorders have also been found in ruminants, resulting in retarded fetal development, early embryonic mortality, abortions, stillbirths, births of weak newborn, prolonged gestation, placental retention, and low thyroid hormone concentrations (Hetzel and Mano, 1989; European Union Scientific Committee on Food, 2002; Ferri et al., 2003). In growing male lambs, a deficiency of iodine causes hypothyroidism, which leads to retardation of growth and reduced wool production and interferes with sexual maturity (Sokkar et al., 2000). In gestating ewes, severe iodine deficiency reduces fetal brain weight and BW (Potter et al., 1982).

Meschy (2000) reported that the iodine requirement is usually higher in goats than in other ruminants: a dietary iodine concentration considered adequate to the dairy cow $(0.3 \mathrm{mg} / \mathrm{kg}$ of $\mathrm{DM})$ is not sufficient to prevent goiter in kids if fed to goats. Even though the use of an iodine supplement in dairy goats should be a common practice, a large database on iodine requirements in dairy goats is not available. The concentration of dietary iodine recommended by the NRC (2007) is $0.5 \mathrm{mg} / \mathrm{kg}$ of DM of the diet in growing and nonlactating goats and $0.8 \mathrm{mg} / \mathrm{kg}$ of $\mathrm{DM}$ for lactating goats, 
although these recommendations are based on a limited number of data.

The European Commission asked the European Food Safety Authority (2005) to evaluate the physiological requirements for iodine of the different animal species and to advise the Commission on the possible detrimental effects of the current concentration authorized under Directive 1459/2005/EC. Based on the data available, a maximum tolerable concentration of 10 $\mathrm{mg} / \mathrm{kg}$ of feed was established in all species, excluding horses. However, Mantovani et al. (2006) mentioned that reducing iodine concentration to a maximum of $4 \mathrm{mg} / \mathrm{kg}$ of complete feed for dairy cows could result in a satisfactory margin of safety for the consumption of milk, still fulfilling the iodine requirements in farm animals. In one experiment on dairy cows, increasing supplemental iodine from 6.8 to $68.0 \mathrm{mg} / \mathrm{d}$ did not change milk production and composition (Hemken et al., 1972). In reality, information about the effects of iodine supplementation on milk yield and milk composition in dairy animals, especially in dairy goats, is rather scarce. The aims of this work were to investigate the effects of continuous supplementation of KI to dairy goats on milk yield and composition, and on the enrichment of goat milk with iodine.

\section{MATERIALS AND METHODS}

\section{Experimental Site, Trial Duration, Animals, and Treatments}

The experiment was carried out during spring 2007 (May to June) at the Bonassai research farm (northwest Sardinia, Italy, $41^{\circ} \mathrm{N}, 33 \mathrm{~m}$ above sea level, mean annual rainfall $590 \mathrm{~mm}$ ). The experiments on the animals followed the European Commission Council Directive (86/609/EEC) regulating the use of animals for experimental and other scientific purposes in the European Union.

Thirty goats belonging to the Sarda population (crossbreed of autochthonous animals with Maltese breed) in midlactation (DIM, mean \pm SD: $113 \pm 3$ d) were used. The goats were randomly assigned to 3 experimental homogeneous groups on the basis of live weight $(44.4 \pm 1.4 \mathrm{~kg})$, milk yield $(1,284 \pm 69 \mathrm{~g})$, and milk composition. Each goat was supplemented with 0 (control group), 0.45 (iodine level 1), or 0.90 (iodine level 2) $\mathrm{mg}$ of KI/d. The dose of KI (76.5\% of iodine) was administered every day for 10 weeks as iodized salt dissolved in water in a $30 \%$ (wt/vol) solution. Because the concentration of $\mathrm{KI}$ was $30 \mathrm{mg} / \mathrm{kg}$ of salt, the amount of iodized salt administered was 0,15 , and 30 $\mathrm{g} / \mathrm{d}$ per goat in the control group, group 1 , and group 2 , respectively. The assigned amount of iodine was dosed after each morning milking and administered to each goat by using a manual syringe gun. The trial lasted 10 wk: 2 wk of adaptation and 8 wk of data collection. The goats were milked twice daily at 0700 and $1700 \mathrm{~h}$. On the basis of estimated energy and protein requirements (INRA, 1988), each group of animals was fed ryegrass hay (on average $1.4 \mathrm{~kg} / \mathrm{d}$ per goat, as fed), split into 2 feedings (morning and evening), and each animal was individually fed a commercial concentrate $(0.7 \mathrm{~kg} / \mathrm{d}$ per goat, as fed) during both milkings. Drinking water was always available to the animals. Milk yield was recorded weekly and milk samples were collected weekly at the morning and evening milkings. Individual intake of concentrate and average group intake of hay were measured daily by weighing the amount offered and the corresponding orts after each meal (concentrate) or after $24 \mathrm{~h}$ (hay). Samples of dietary ingredients (concentrate and hay) were collected every week during the experimental period for DM determination and for chemical analysis, including iodine content.

\section{Feed and Milk Analysis}

The DM content of the feed was determined by ovendrying at $105^{\circ} \mathrm{C}$ for $24 \mathrm{~h}$. Dried feed samples were analyzed for NDF, ADF, and acid detergent lignin with the procedure of Van Soest et al. (1991), by using the filter bag equipment of Ankom (Ankom Technology Corp., Fairport, NY), ash (AOAC, 2000; method 942.05), CP (AOAC, 2000; method 988.05), and lipid extract (AOAC, 2000; method 920.39). Chemical analyses were expressed as percentages of DM.

Individual milk samples of morning and evening milkings were analyzed for fat, nitrogen $(\mathrm{N} \times 6.38)$, lactose (infrared method, MilkoScan 4000, Foss, Hillerød, Denmark), urea (differential pH measurements, CL10, Micro-Eurochem, Rome, Italy), and SCC (Fossomatic 5000 , Foss). Iodine concentration in the iodized salt, in feeds, and in milk samples was measured using a spectrophotometric method based on the Sandell-Kolthoff reaction, as described by Dunn et al. (1993).

The percentage of iodine excreted in milk was calculated for each goat as the ratio between the total output of iodine in milk (sum of iodine excreted at each milking) and the sum of iodine intake from supplement (calculated as KI administered $\times 0.765$ ), concentrate, and hay. Because no individual hay intake was measured, the mean hay intake per group was used for this calculation.

\section{Statistical Analysis}

Data were analyzed with the following mixed linear model according to a repeated measures design (Littell et al., 1998): 
Table 1. Chemical composition of the feeds used in the diets (DM basis)

\begin{tabular}{lcc}
\hline Chemical composition $^{1}$ & Concentrate $^{2}$ & Hay \\
\hline DM, \% & 93.2 & 90.8 \\
CP, \% & 10.84 & 5.81 \\
NDF, \% & 31.79 & 58.74 \\
ADF, \% & 19.12 & 38.49 \\
ADL, \% & 2.96 & 4.29 \\
Ash, \% & 10.84 & 9.00 \\
Lipid extract, \% & 2.03 & 1.41 \\
Iodine, mg/kg of DM & 0.63 & 0.19 \\
\hline
\end{tabular}

${ }^{1} \mathrm{ADL}=$ acid detergent lignin.

${ }^{2}$ Commercial concentrate with mineral supplement: iodine $\left[\mathrm{Ca}\left(\mathrm{IO}_{3}\right)_{2}\right]$, $1 \mathrm{mg} / \mathrm{kg}$; $\mathrm{Co}\left(\mathrm{CoCO}_{3}\right), 0.40 \mathrm{mg} / \mathrm{kg} ; \mathrm{Fe}\left(\mathrm{FeCO}_{3}\right), 72 \mathrm{mg} / \mathrm{kg} ; \mathrm{MnO}, 60.0$ $\mathrm{mg} / \mathrm{kg} ; \mathrm{ZnO}, 70.0 \mathrm{mg} / \mathrm{kg} ; \mathrm{Se}\left(\mathrm{Na}_{2} \mathrm{SeO}_{3}\right), 0.25 \mathrm{mg} / \mathrm{kg} ; \mathrm{Mo}\left[\left(\mathrm{NH}_{4}\right)_{2} \mathrm{MoO}_{4}\right]$, $0.20 \mathrm{mg} / \mathrm{kg}$.

$$
\mathrm{Y}_{\mathrm{ijkl}}=\mu+\mathrm{S}_{\mathrm{i}}+\mathrm{W}_{\mathrm{j}}+(\mathrm{S} \times \mathrm{W})_{\mathrm{ij}}+\mathrm{A}_{\mathrm{k}}(\mathrm{i})+\varepsilon_{\mathrm{ijkl}},
$$

where $Y_{i j k l}$ are observations, $\mu$ is the overall mean, $S_{i}$ is the fixed effect of iodine supplement $\mathrm{i}(\mathrm{i}=3), \mathrm{W}_{\mathrm{j}}$ is the fixed effect of week $\mathrm{j}(\mathrm{j}=8),(\mathrm{S} \times \mathrm{W})_{\mathrm{ij}}$ is the interaction between supplement and week, $A_{k}(i)$ is the random effect of animal $\mathrm{k}(\mathrm{k}=30)$ nested within diet $\mathrm{i}$, and $\varepsilon_{\mathrm{ijkl}}$ is the random residual. Comparisons among treatment means were performed by using the Tukey test. Differences were considered significant at $P \leq$ 0.05. Linear and quadratic effects of treatments were also estimated.

\section{RESULTS AND DISCUSSION}

Chemical composition of the experimental diets is reported in Table 1. During the experimental period, the concentrate was completely eaten by all groups and the average daily hay intake was $1,397,1,394$, and 1,390 $\mathrm{g} / \mathrm{d}$ per goat in groups 0,1 , and 2 respectively. The content of iodine measured in the commercial concentrate averaged $0.63 \mathrm{mg} / \mathrm{kg}$ of $\mathrm{DM}$, whereas that measured in hay was $0.19 \mathrm{mg} / \mathrm{kg}$ of DM. The basal concentration of iodine in the diet was $0.34 \mathrm{mg} / \mathrm{kg}$ of $\mathrm{DM}$, which is almost $50 \%$ of the dietary iodine concentration recommended by NRC (2007) for lactating goats $(0.8 \mathrm{mg} / \mathrm{kg}$ of DM diet) and is considered adequate for dairy cows $(0.3 \mathrm{mg} / \mathrm{kg}$ of DM diet).

\section{Milk Yield and Composition}

Milk yield and milk composition are reported in Table 2. Milk yield was not influenced by KI supplementation. Similar results have been observed in dairy cows (Hemken et al., 1972; Wiewióra et al., 2004; Grace and Waghorn, 2005), even with a very high dose of iodine supplementation $(68 \mathrm{mg} / \mathrm{d}$ per goat; Hemken et al., 1972). Milk yield decreased during the trial in all experimental groups (Figure 1), following the natural evolution of the lactation curve in dairy goats (Macciotta et al., 2005).

Only the first level of KI supplementation increased the content of milk fat significantly compared with that of the unsupplemented group. For this result, there is no explanation except for a random fluctuation of the samples. Temporal evolution of fat content (Figure 2) evidenced a trend opposite that of milk yield because of a concentration effect. The lactose content was reduced by the highest level of iodine supplementation, as reported previously in Red and White cows supplemented with iodine and selenium (Wrzol et al., 1999). The SCC did not show a clear trend in relation to KI supplementation level. Milk protein content and yield were not influenced by KI supplementation (Table 2, Figure 3). The content of MUN was significantly lower in groups that received KI supplementation (Table 2, Figure 4). The reduction in MUN followed the linear reduction of BUN (Nudda et al., 2009) as iodine supplementation increased.

\section{Milk lodine Content}

The iodine content in milk did not differ between goats receiving the dose of $\mathrm{KI}$ in group 1 and the control group, but was significantly higher in group 2 (Table 2). The milk iodine content increased quadratically as dietary iodine supplementation increased (Figure 5). The enrichment of iodine concentration in milk reached approximately $31 \%$ in group 1 and $117 \%$ in group 2 compared with the control group. Groppel (1991) noted that the colostrum and milk of sheep and goats contained more iodine than the milk of cows under the same diet, and iodine concentrations of less than $62 \mu \mathrm{g} / \mathrm{L}$ in goats and $79 \mu \mathrm{g} / \mathrm{L}$ in sheep are considered deficient. A survey carried out in 54 ovine flocks reported that in 2 flocks in which newborn lambs had

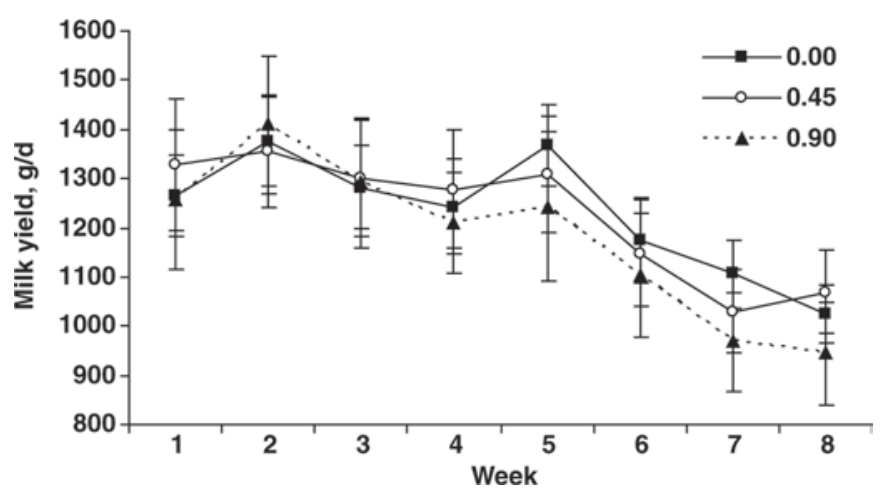

Figure 1. Temporal evolution of milk yield in dairy goats supplemented with $0,0.45$, and $0.90 \mathrm{mg} / \mathrm{d}$ of $\mathrm{KI}$. 


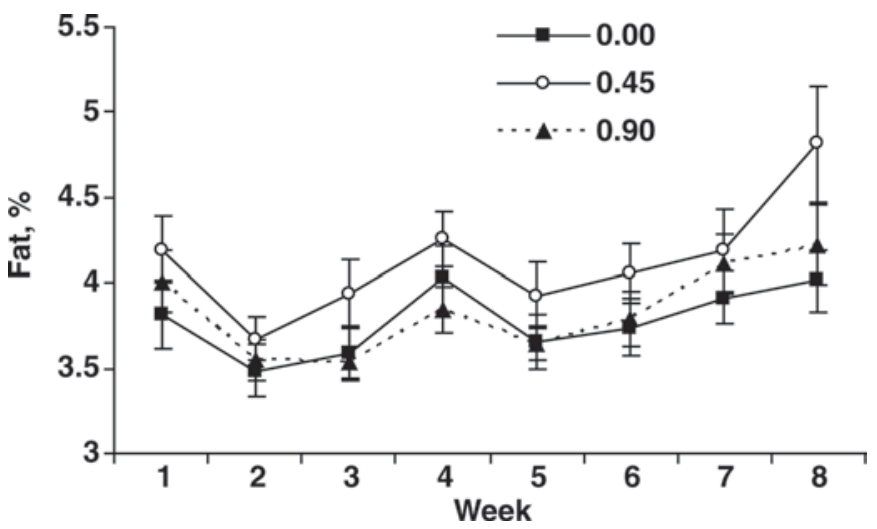

Figure 2. Temporal evolution of milk fat content in dairy goats supplemented with $0,0.45$, and $0.90 \mathrm{mg} / \mathrm{d}$ of KI.

goiter, the iodine concentrations in milk ranged from 45 to $98 \mu \mathrm{g} / \mathrm{L}$ (Azuolas and Caple, 1984). On the basis of this report, the content of milk iodine in our control group should be considered deficient as a consequence of a deficit of iodine in the diet. At this concentration, goats could suffer from thyroid gland disorders, with negative consequences on reproductive performance. In dairy cows, a concentration of iodine on pasture of 0.24 $\mathrm{mg} / \mathrm{kg}$ of DM resulted in milk iodine concentrations of less than $20 \mu \mathrm{g} / \mathrm{L}$.

Dynamics of iodine concentration in the milk of goats during continuous administration of $\mathrm{KI}$ is presented in Figure 6. Supplementation of iodine resulted in milk with a higher concentration from wk 1, especially at

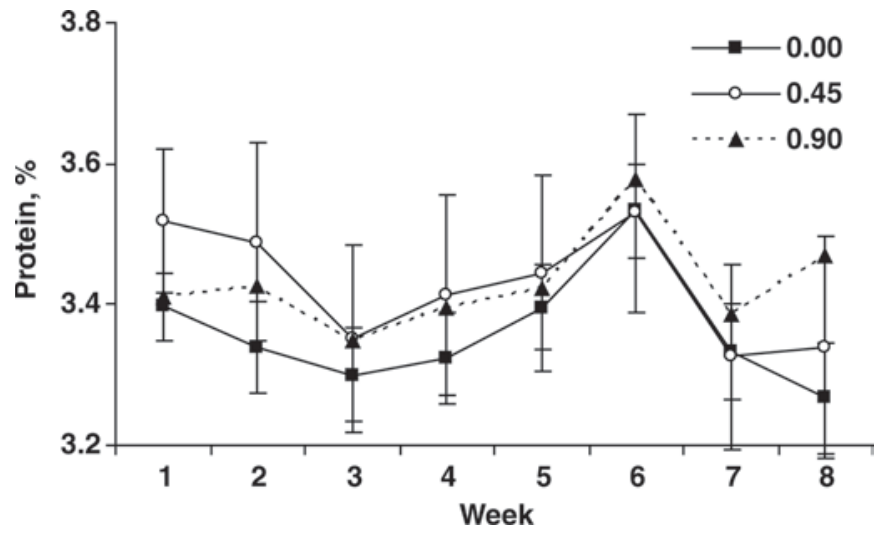

Figure 3. Temporal evolution of milk protein content in dairy goats supplemented with $0,0.45$, and $0.90 \mathrm{mg} / \mathrm{d}$ of KI.

the highest level of supplementation. Milk iodine concentration within groups showed a high variability among weeks, especially in the group that received the highest dose of KI. This variability should be related to the intrathyroidal pool of iodine accumulated during continuous KI supplementation, which regulates the concentration of the halogen in the thyroid gland. The variability also observed in the control group suggests an effect attributable to the intake of concentrate, which contained $0.6 \mathrm{mg}$ of iodine $/ \mathrm{kg}$ of DM.

The transfer of iodine (iodine excreted in milk/total iodine intake) averaged $11.2 \%$ in group $0,9.4 \%$ in group 1 , and $11.3 \%$ in group 2 , without significant differences among iodine supplementation levels because

Table 2. Milk yield, composition, and iodine content of milk from goats supplemented with different doses of $\mathrm{KI}$

\begin{tabular}{|c|c|c|c|c|c|c|}
\hline \multirow[b]{2}{*}{ Item } & \multicolumn{3}{|c|}{ Iodine level ${ }^{1}$} & \multicolumn{3}{|c|}{$P$-level } \\
\hline & 0 & 1 & 2 & Iodine level & Week & Interaction \\
\hline Milk yield, $\mathrm{g} / \mathrm{d}$ & 1,229 & 1,227 & 1,179 & NS & NS & NS \\
\hline Fat \% & $3.78^{\mathrm{A}}$ & $4.12^{\mathrm{B}}$ & $3.84^{\mathrm{A}}$ & $* *^{2}$ & $* *$ & NS \\
\hline Fat yield, g/d & $45.9^{\mathrm{a}}$ & $50.0^{\mathrm{b}}$ & $44.6^{\mathrm{a}}$ & $*$ & $\dagger$ & NS \\
\hline Protein, $\%$ & 3.36 & 3.43 & 3.43 & NS & NS & NS \\
\hline Protein vield, $\mathrm{g} / \mathrm{d}$ & 41.0 & 41.1 & 39.8 & NS & $* *$ & NS \\
\hline Lactose, $\%$ & $4.33^{\mathrm{A}}$ & $4.38^{\mathrm{A}}$ & $4.25^{\mathrm{B}}$ & $* *^{2}$ & ** & NS \\
\hline $\ln \mathrm{SCC}, \times 1,000 / \mathrm{mL}$ & $6.71^{\mathrm{e}}$ & $6.38^{\mathrm{f}}$ & $6.52^{\mathrm{ef}}$ & $\dagger$ & $* *$ & NS \\
\hline MUN, mg/dL & $36.8^{\mathrm{B}}$ & $32.3^{\mathrm{A}}$ & $32.8^{\bar{A}}$ & $* *$ & $* *$ & NS \\
\hline Iodine, $\mu \mathrm{g} / \mathrm{L}$ & $60.1^{\mathrm{A}}$ & $78.8^{\mathrm{A}}$ & $130.2^{\mathrm{B}}$ & $* * 3$ & NS & NS \\
\hline Iodine vield, $\mu \mathrm{g} / \mathrm{d}$ & $74.5^{\mathrm{A}}$ & $94.5^{\mathrm{A}}$ & $150.3^{\mathrm{B}}$ & $* *$ & $* *$ & NS \\
\hline Iodine transfer ${ }^{4}$ & 11.2 & 9.4 & 11.3 & NS & ** & NS \\
\hline
\end{tabular}

${ }^{\mathrm{a}, \mathrm{b}}$ Means within a row with different superscripts differ $(P<0.05)$.

e,f Means within a row with different superscripts differ $(P<0.10)$.

${ }^{\mathrm{A}, \mathrm{B}}$ Means within a row with different superscripts differ $(P<0.01)$.

${ }^{1}$ Iodine level: $0=$ control; $1=0.45 \mathrm{mg} / \mathrm{d}$ of KI supplement; $2=0.90 \mathrm{mg} / \mathrm{d}$ of KI supplement.

${ }^{2}$ Denotes effect of linear and quadratic contrasts.

${ }^{3}$ Denotes effect of quadratic contrast.

${ }^{4}$ Iodine transfer: [iodine excreted in milk/total iodine intake] $\times 100$.

$\dagger P \leq 0.10 ;{ }^{*} P \leq 0.05 ;{ }^{* *} P \leq 0.01$. 


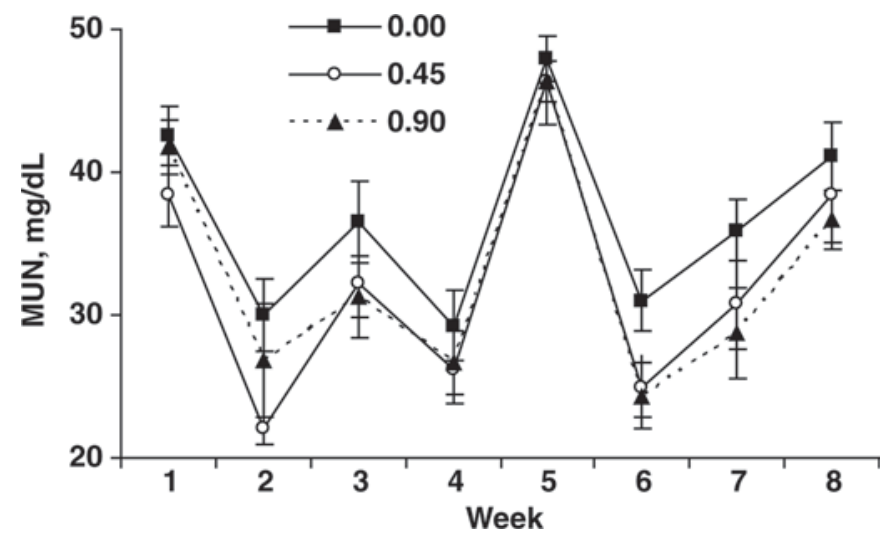

Figure 4. Temporal evolution of MUN in dairy goats supplemented with $0,0.45$, and $0.90 \mathrm{mg} / \mathrm{d}$ of $\mathrm{KI}$.

of the high within-group variability $(\mathrm{SE}=1.44)$. These figures are lower than values previous reported for ruminant species.

\section{CONCLUSIONS}

The supplementation of dairy goat diets with iodine at the highest dose used in this trial (nearly $1 \mathrm{mg}$ of $\mathrm{KI} / \mathrm{d}$ per goat) increased the milk iodine content significantly. This dose of iodine supplementation doubled the milk iodine content compared with that of the control group. Iodine supplementation did not influence milk yield. No evident effect on gross composition of milk was observed. The reduction of MUN by the 2 levels of iodine supplementation observed in this trial requires further investigation.

\section{ACKNOWLEDGMENTS}

This research was supported by the Italian Ministry of University and Research, FISR (Fondo Integrativo Speciale per la Ricerca) grant. The authors are grateful

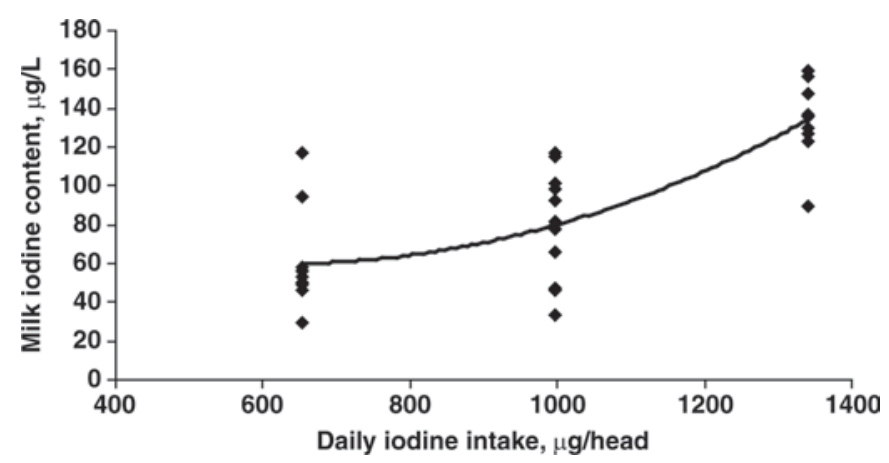

Figure 5. Relationship between daily iodine intake and milk iodine content in dairy goats.

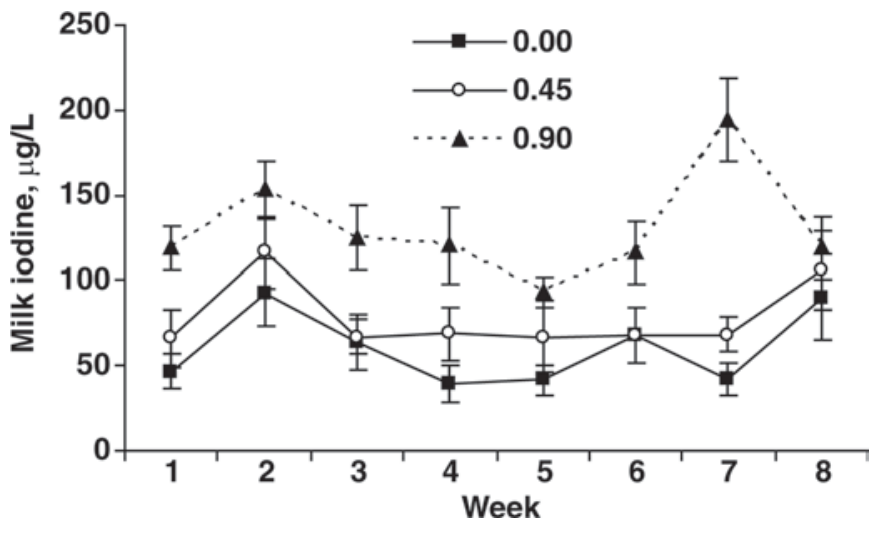

Figure 6. Temporal evolution of milk iodine content in dairy goats supplemented with $0,0.45$, and $0.90 \mathrm{mg} / \mathrm{d}$ of KI.

to the technicians from the Dipartimento di Scienze Zootecniche (University of Sassari, Italy), Ana Helena Dias Francesconi for reviewing and editing the manuscript, and Gesumino Spanu for technical assistance during the experiment.

\section{REFERENCES}

AOAC. 2000. Official Methods of Analysis. 17th ed. Assoc. Off. Anal. Chem., Arlington, VA.

Azuolas, J. K., and I. W. Caple. 1984. The iodine status of grazing sheep as monitored by concentrations of iodine in milk. Aust. Vet. J. $61: 223-227$.

de Benoist, B., E. McLean, M. Andersson, and L. Rogers. 2008. Iodine deficiency in 2007: Global progress since 2003. Food Nutr. Bull. $29: 195-202$.

Delange, F. 2002. Iodine deficiency in Europe. Thyroid Int. 5:3-18.

Dunn, J. T., H. E. Crutchfield, R. Gutekunst, and A. T. Dunn. 1993. Two simple methods for measuring iodine in urine. Thyroid 3:119-123.

European Food Safety Authority. 2005. Opinion of the Scientific Panel on Additives and Products or Substances used in Animal Feed on the request from the Commission on the use of iodine in feedingstuffs. (Question NoEFSAQ-2003-058). http://www.efsa. europa.eu/cs/BlobServer/Scientific_Opinion/Iodine_adopted. pdf?ssbinary=true Accessed Jan. 8, 2009.

European Union Scientific Committee on Food. 2002. Opinion of the Scientific Committee on Food on the tolerable upper intake level of iodine. http://ec.europa.eu/food/fs/sc/scf/out146_en.pdf Accessed Jan. 14, 2009.

Ferri, N., S. Ulisse, F. Aghini-Lombardi, F. M. Graziano, T. Di Mattia, F. P. Russo, M. Arizzi, E. Baldini, P. Trimboli, D. Attanasio, A. Fumarola, A. Pinchera, and M. D'Armiento. 2003. Iodine supplementation restores fertility of sheep exposed to iodine deficiency. J. Endocrinol. Invest. 26:1081-1087.

Galton, D. M., L. G. Petersson, and H. N. Erb. 1986. Milk iodine residues in herds practicing iodophor premilking teat disinfection. J. Dairy Sci. 69:267-271.

Grace, N. D., and G. C. Waghorn. 2005. Impact of iodine supplementation of dairy cows on milk production and iodine concentrations in milk. N. Z. Vet. J. 53:10-13.

Groppel, B. 1991. Jodmangel beim Tier. Pages 127-156 in Mineralstoffe und Spurenelemente in der Ernährung. M. Anke and M., ed. Verlag Media Touristik, Gersdorf, Germany.

Hemken, R. W., J. H. Vandersall, M. A. Oskarsson, and L. R. Fryman. 1972. Iodine intake related to milk iodine and performance of dairy cattle. J. Dairy Sci. 55:931-934. 
Herzig, I., J. Poul, B. Pisarikova, and E. Göpfert. 2003. Milk iodine concentration in cows treated orally or intramuscularly with a single dose of iodinated fatty acid esters. Vet. Med. Czech 48:155162.

Hetzel, B. S., and M. T. Mano. 1989. A review of experimental studies of iodine deficiency during fetal development. J. Nutr. 119:145151.

INRA. 1988. Alimentation de caprins. Pages 280-304 in Alimentation des Bovins, Ovins et Caprins. R. Jarrige, ed. INRA Paris, France.

Littell, R. C., P. R. Henry, and C. B. Ammerman. 1998. Statistical analysis of repeated measures data using SAS procedures. J. Anim. Sci. 76:1216-1231.

Macciotta, N. P. P., P. Fresi, G. Usai, and A. Cappio-Borlino. 2005. Lactation curves of Sarda breed goats estimated with test day models. J. Dairy Res. 72:470-475.

Mantovani, A., F. Maranghi, I. Purificato, and A. Macrì. 2006. Assessment of feed additives and contaminants: An essential component of food safety. Ann. Ist. Super. Sanità 42:427-432.

Meschy, F. 2000. Recent progress in the assessment of mineral requirements of goats. Livest. Prod. Sci. 64:9-14.

NRC. 2007. Nutrient Requirements of Small Ruminants. Natl. Acad. Press, Washington, DC.

Nudda, A., G. Battacone, G. Bomboi, B. Floris, and G. Pulina. 2009. Thyroid hormones and blood metabolites of dairy goats supplemented with dietary iodine. J. Dairy Science 92(Suppl. 1):304. (Abstr.)
Potter, B. J., M. T. Mano, G. B. Belling, G. H. McIntosh, C. Hua B. G. Cragg, J. Marshall, M. L. Wellby, and B. S. Hetzel. 1982. Retard fetal brain development resulting from severe dietary iodine deficiency in sheep. Neuropathol. Appl. Neurobiol. 8:303-313.

Sokkar, S. M., A. H. Soror, Y. F. Ahmed, O. H. Ezzo, and M. A Hamouda. 2000. Pathology and biochemical studies on experimental hypothyroidism in growing lambs. J. Vet. Med. Infect. Dis. Vet. Public Health 47:641-652.

Van Soest, P. J., D. A. Robertson, and B. A. Lewis. 1991. Methods for dietary fiber, neutral detergent fiber and non-starch polysaccharides in relation to animal nutrition. J. Dairy Sci. 74:3583-3597.

Vitti, P., T. Rago, F. Aghini-Lombardi, and A. Pinchera. 2001. Iodine deficiency disorders in Europe. Public Health Nutr. 4:529-535.

World Health Organization. 2007. Assessment of Iodine Deficiency Disorders and Monitoring Their Elimination: Guide for Programme Managers. 3rd ed. http://whqlibdoc.who.int/ publications/2007/9789241595827_eng.pdf Accessed Mar. 11, 2009

Wiewióra, W., F. Brzóska, B. Brzóska, and M. Pietras. 2004. Iodine and selenium concentration in cows' milk and plasma and its relation to milk yield, mineral content and selected metabolic parameters. Ann. Anim. Sci. 4:79-90.

Wrzol, J., F. Brzoska, and J. Szarek. 1999. Effect of iodine and selenium dietary level on performance of cows and composition of milk fatty acids. Rocz. Nauk. Zootech. 26:159-173. 